\title{
Effects of Weaning Age at 21 and 28 Days on Growth Performance, Intestinal Morphology and Redox Status in Piglets
}

\author{
Dongxu Ming ${ }^{1}$, Wenhui Wang ${ }^{1}$, Caiyun Huang ${ }^{1}$, Zijie Wang ${ }^{1}$, Chenyu Shi ${ }^{1}$, Jian Ding ${ }^{2}$, Hu Liu ${ }^{1, *}$ \\ and Fenglai Wang ${ }^{1}$ \\ 1 State Key Laboratory of Animal Nutrition, College of Animal Science and Technology, China Agricultural \\ University, Beijing 100193, China; mdx920825@163.com (D.M.); wangwh1025@cau.edu.cn (W.W.); \\ huangcaiyun@cau.edu.cn (C.H.); wzjgf191114@163.com (Z.W.); scyshichenyu@163.com (C.S.); \\ wangfl@cau.edu.cn (F.W.) \\ 2 National Animal Husbandry Service, Building No. 20, Maizidian Street, Beijing 100125, China; \\ Dingjian1029@126.com \\ * Correspondence: liuhu0674@cau.edu.cn; Tel./Fax: +86-010-6273-3586
}

check for updates

Citation: Ming, D.; Wang, W.; Huang, C.; Wang, Z.; Shi, C.; Ding, J.; Liu, H.; Wang, F. Effects of Weaning Age at 21 and 28 Days on Growth Performance, Intestinal Morphology and Redox Status in Piglets. Animals 2021, 11, 2169. https://doi.org/ $10.3390 /$ ani11082169

Academic Editors: Lin Xi and Ignacio Badiola

Received: 24 June 2021

Accepted: 20 July 2021

Published: 22 July 2021

Publisher's Note: MDPI stays neutral with regard to jurisdictional claims in published maps and institutional affiliations.

Copyright: (c) 2021 by the authors. Licensee MDPI, Basel, Switzerland. This article is an open access article distributed under the terms and conditions of the Creative Commons Attribution (CC BY) license (https:// creativecommons.org/licenses/by/ $4.0 /)$.
Simple Summary: After weaning, pigs are subjected to a variety of nutritional, psychological and environmental stresses. Historically, weaning age was determined knowing that antibiotics could be included in postweaning diets for piglets. The use of antibiotic growth promoters to help prevent weaning stress in weaned pigs has been forbidden in Japan, Korea, the European Union and China. In this study, intestinal morphology, $\mathrm{pH}$ of the stomach and antioxidant status of pigs weaned at $28 \mathrm{~d}$ were better than pigs weaned at $21 \mathrm{~d}$. These results indicated that strategies including enhancing the intestinal absorption function and antioxidant ability in weaned pigs can improve growth performance and decrease diarrhea incidence.

\begin{abstract}
The study objective was to assess effects of different weaning ages on growth performance, intestinal morphology and redox status in Duroc $\times$ Landrace $\times$ Large White piglets $(n=96)$ fed diets without antibiotic growth promoters. Piglets were selected from 24 litters based on similar body weight at $14 \mathrm{~d}$ of age. All piglets were allocated to two groups in a completely random design with six replicates and eight pigs per replicate (four barrows and four gilts), which were weaned at 21 ( $n=48$; $\mathrm{BW}=6.87 \pm 0.33 \mathrm{~kg})$ and $28(\mathrm{n}=48 ; \mathrm{BW}=8.49 \pm 0.41 \mathrm{~kg})$ days of age. After weaning, pigs were fed a corn-soybean meal-based diet. Average daily gain (ADG), average daily feed intake (ADFI), feed conversion $(\mathrm{F}: \mathrm{G})$, diarrhea incidence, gastrointestinal $\mathrm{pH}$, intestinal morphology and redox status were determined. Pigs weaned at $28 \mathrm{~d}$ displayed increased ADG from d 8 to $14(p<0.01)$ compared with pigs weaned at $21 \mathrm{~d}$. Pigs weaned at $28 \mathrm{~d}$ had a higher ADFI from d 0 to $7(p<0.01), \mathrm{d} 8$ to 14 $(p<0.01), \mathrm{d} 15$ to $28(p<0.05)$ and during the entire experimental period $(p<0.01)$ compared with pigs weaned at $21 \mathrm{~d}$. Pigs weaned at $21 \mathrm{~d}$ had an improved F:G from $\mathrm{d} 15$ to $28(p<0.05)$ compared with pigs weaned at $28 \mathrm{~d}$. Pigs weaned at $28 \mathrm{~d}$ had decreased diarrhea incidence from $\mathrm{d} 8$ to 14 $(p<0.01)$ and the entire experimental period $(p<0.01)$ compared with pigs weaned at $21 \mathrm{~d}$. On $\mathrm{d}$ 28 , the $\mathrm{pH}$ of the stomach contents in pigs weaned at $21 \mathrm{~d}$ was significantly higher compared with pigs weaned at $28 \mathrm{~d}(p<0.01)$. On $\mathrm{d} 14$, the morphology of the duodenum, jejunum and ileum in pigs weaned at $28 \mathrm{~d}$ was improved compared with pigs weaned at $21 \mathrm{~d}$. During the experiment period, the antioxidant abilities of pigs weaned at $28 \mathrm{~d}$ of the heart, liver, kidney, intestinal and serum were better than pigs weaned at $21 \mathrm{~d}$. In conclusion, intestinal morphology, $\mathrm{pH}$ of the stomach and antioxidant status of pigs weaned at $28 \mathrm{~d}$ were better than pigs weaned at $21 \mathrm{~d}$. These factors supported better growth performance and decreased diarrhea incidence.
\end{abstract}

Keywords: weaned pigs; weaning age; growth performance; redox status; intestinal morphology 


\section{Introduction}

Weaning is a necessary step in pig production. After weaning, pigs are subjected to a variety of nutritional, psychological and environmental stresses [1,2]. Historically, weaning age was determined knowing that antibiotics could be included in postweaning diets for piglets. Widespread use of antibiotic growth promoters has facilitated the development of antibiotic-resistant bacteria and increased chances of antibiotic residues which threaten the safety of humans. Consequently, the use of antibiotic growth promoters in feed for livestock and poultry has been banned in Japan, Korea and the European Union [3]. In China, the addition of antibiotic growth promoters to livestock and poultry feed was also forbidden in 2020 [4]. Forbidding the use of antibiotic growth promoters in feed may lead to new challenges in swine production, such as lower growth performance and higher diarrhea incidence in piglets. However, little is known about the optimal weaning age for piglets when dietary antibiotics are not available postweaning. In the European Union, $28 \mathrm{~d}$ is the normal age at weaning (welfare legislation) but $21 \mathrm{~d}$ is the minimum if specific structures for weaned piglets are available [5].

If piglets are weaned too late, the reproductive efficiency of sows is compromised [6]. Alternatively, if piglets are weaned too early, weaning stress caused by changes in feed and the environment will have a great negative impact on the growth and development of piglets [7]. Weaning induces oxidative stress in piglets regardless of weaning age [8]. Growth performance of pigs weaned at 14-23 days of age was significantly lower than that of pigs weaned at 28-35 days of age [9-11]. When using dietary antibiotics, growth performance of weaned pigs increases linearly with increasing weaning age to $25 \mathrm{~d}$, which seems to be the optimal weaning age $[12,13]$. Weaning stress causes pigs to produce a high concentration of free radicals which destroys the redox equilibrium of pigs [14]. This condition leads to intestinal epithelial cell damage, and destruction of intestinal morphology and structure in weaned pigs. These changes depress feed intake and growth rate and can lead to diarrhea, inflammatory reactions, death and other phenomena in weaned pigs [15].

The weaning period is also an important period for the intestinal development of pigs. During this period, digestion, immunity, metabolism and other aspects of pigs change rapidly. The damage to intestinal morphology and structure caused by weaning is reconstructed during the maturation of intestinal function [16]. Weaning impairs the intestinal barrier of pigs. Compromised intestinal barrier function easily leads to intestinal allergy and activation of some neural regulatory pathways. At this time, viruses and bacteria can invade the intestine and cause diarrhea in piglets [17-19].

Therefore, selection of the optimal weaning age is crucial to the success of pig production in a future that does not permit antibiotic use in diets. The purpose of this study was to investigate the growth performance, intestinal morphology and antioxidant activity of piglets weaned at 21 or $28 \mathrm{~d}$ fed diets without antibiotic growth promoters.

\section{Materials and Methods}

The protocol (No. AW30301202-1-1) employed in this trial was approved by the China Agricultural University Animal Care and Use Committee (Beijing, China).

\subsection{Pigs and Experimental Protocol}

Duroc $\times$ Landrace $\times$ Large White piglets $(n=96)$ were random selected at 14 days old from 24 litters based on body weight and sex. All piglets were allocated to 2 groups in a completely random design with six replicate pens and eight pigs per replicate pen (four barrows and four gilts). Additionally, piglets continued to breastfeed from the original dam until weaning. Pigs were weaned at $21(\mathrm{n}=48$; $\mathrm{BW}=6.87 \pm 0.33 \mathrm{~kg})$ or $28(\mathrm{n}=48$; $\mathrm{BW}=8.49 \pm 0.41 \mathrm{~kg}$ ) days of age.

After weaning, pigs were fed a corn-soybean meal-based diet (without growth promoter) (Table 1). The basal diet was formulated to meet or exceed NRC (2012) recommendations for weaned pigs [20]. Pigs were housed in pens with a totally slatted floor 
$(1.2 \times 2.0 \mathrm{~m})$ containing a nipple drinker and stainless-steel feeder for ad libitum access to water and feed over the $28 \mathrm{~d}$ trial. An ambient room temperature was maintained at $29{ }^{\circ} \mathrm{C}$ for the first week, and lowered by $1^{\circ} \mathrm{C}$ each week thereafter. Fecal scores were recorded daily for all pigs from $\mathrm{d} 1$ to 28 by the same person and were based on the following scale: 1 = well-formed feces, 2 = sloppy feces, 3 = diarrhea [21]. Pigs with a score of 3 were considered to have diarrhea. The incidence of diarrhea for piglets in each pen was calculated as [(number of piglets with diarrhea $\times$ number of days of diarrhea)/(total number of piglets $\times$ number of days of experiment)] $\times 100$ [22]. Body weight was measured on $d 0,7,14$ and 28 and feed disappearance on these days was recorded. ADG, ADFI and F:G were calculated based on weight measurements. The final body weight was measured at 56 days of age.

Table 1. Composition and analyzed nutrient composition of experimental diets (as-fed basis).

\begin{tabular}{|c|c|}
\hline Item & \\
\hline \multicolumn{2}{|l|}{ Ingredients, $\%$} \\
\hline Corn & 59.34 \\
\hline Soybean meal ( $45 \%$ crude protein) & 15.00 \\
\hline Extruded soybean ( $36 \%$ crude protein) & 5.00 \\
\hline Soy protein concentrate (65\% crude protein) & 2.00 \\
\hline Fish meal (68\% crude protein) & 3.00 \\
\hline Dried whey ( $12 \%$ crude protein) & 6.00 \\
\hline $\mathrm{SDPP}^{1}$ & 2.00 \\
\hline Soybean oil & 2.20 \\
\hline Sucrose & 2.00 \\
\hline Limestone & 0.90 \\
\hline Dicalcium phosphate & 1.00 \\
\hline Salt & 0.25 \\
\hline L-Lysine $\cdot \mathrm{HCl}$ & 0.48 \\
\hline L-Threonine & 0.16 \\
\hline L-Tryptophan & 0.05 \\
\hline L-Methionine & 0.12 \\
\hline Vitamin and mineral premix ${ }^{2}$ & 0.50 \\
\hline \multicolumn{2}{|l|}{ Nutrient levels ${ }^{3}, \%$} \\
\hline Digestible energy, MJ/kg & 15.10 \\
\hline Crude protein & 20.21 \\
\hline Lysine & 1.54 \\
\hline Methionine & 0.44 \\
\hline Threonine & 0.97 \\
\hline Tryptophan & 0.25 \\
\hline Calcium & 0.81 \\
\hline Total phosphorus & 0.65 \\
\hline
\end{tabular}

${ }^{1}$ SDPP: spray-dried porcine plasma. ${ }^{2}$ Provided the following vitamins and minerals per kg of diet: vitamin A, 11,000 IU as retinyl acetate; vitamin $\mathrm{D}_{3}, 1500 \mathrm{IU}$ as cholecalciferol; vitamin $\mathrm{E}, 44.1 \mathrm{IU}$ as DL- $\alpha$-tocopherol acetate; vitamin $\mathrm{K}_{3}, 4 \mathrm{mg}$ as menadione; vitamin $\mathrm{B}_{1}, 1.4 \mathrm{mg}$; vitamin $\mathrm{B}_{2}, 5.2 \mathrm{mg}$; vitamin $\mathrm{B}_{5}, 20 \mathrm{mg}$; vitamin $\mathrm{B}_{12}, 10 \mu \mathrm{g}$; niacin, $26 \mathrm{mg}$; pantothenic acid, $14 \mathrm{mg}$; folic acid, $0.8 \mathrm{mg}$; biotin, $44 \mu \mathrm{g}$; $\mathrm{Fe}, 100 \mathrm{mg}$ from $\mathrm{FeSO}_{4}$; $\mathrm{Cu}, 16.5 \mathrm{mg}$ from $\mathrm{CuSO}_{4} \cdot 5 \mathrm{H}_{2} \mathrm{O} ; \mathrm{Zn}, 90 \mathrm{mg}$ from $\mathrm{ZnO} ; \mathrm{Mn}, 35 \mathrm{mg}$ from $\mathrm{MnSO}_{4} ; \mathrm{I}, 0.3 \mathrm{mg}$ from KI; Se, $0.3 \mathrm{mg}$ from $\mathrm{Na}_{2} \mathrm{SeO}_{3}$.

${ }^{3}$ Digestible energy is calculated value. Other nutrient levels in the table are analyzed values.

\subsection{Chemical Analysis}

The ingredients and diet were analyzed according to the AOAC (2012) procedure [23], including crude protein, total phosphorus and calcium. For analysis of most amino acids, the ingredients and diet were hydrolyzed in $6 \mathrm{M} \mathrm{HCl}$ for $24 \mathrm{~h}$ at $110^{\circ} \mathrm{C}$. Determination of sulfur amino acid content was carried out after formic acid oxidation (AOAC, 2012). Amino acid analysis was carried out using a liquid chromatograph (Hitachi L-8800 Amino Acid Analyzer, Tokyo, Japan). 


\subsection{Sample Collection and Processing}

After an overnight fast on $\mathrm{d} 14$ and d 28 postweaning, a total of 24 pigs ( 2 pigs per pen) were selected for blood sampling. Selected pigs had body weight closest to the mean body weight of all pigs within the pen. Blood samples were collected from the jugular vein into a vacuum tube without anticoagulant for serum. Serum was separated by centrifugation for $10 \mathrm{~min}$ at $3000 \times \mathrm{g}$ and $4{ }^{\circ} \mathrm{C}$, and stored at $-20^{\circ} \mathrm{C}$ until analysis.

On d 7, d 14 and d 28 postweaning, a total of 36 pigs (12 pigs per time point; 1 pig per pen) were slaughtered using electrical stunning. Immediately after slaughter, the gastrointestinal tract was carefully removed by dissection. The $\mathrm{pH}$ of the stomach, duodenum, jejunum, ileum, cecum and colon contents was measured with an SPK pH meter ( $\mathrm{pH}$-star, DK2730, Herlev, Denmark). Tissue samples from the middle of the duodenum, jejunum and ileum were harvested (approximately 1 to $2 \mathrm{~cm}$ ) and fixed with $4 \%$ formaldehydephosphate buffer and kept at $4{ }^{\circ} \mathrm{C}$ for a microscopic assessment of mucosal morphology. Heart, liver, kidney and jejunum were collected and quickly frozen in liquid nitrogen. Tissue samples were then stored at $-80^{\circ} \mathrm{C}$

\subsection{Measurement of Intestinal Morphology}

Villus height and crypt depth in the duodenum, jejunum and ileum were determined. Cross-sections of intestinal samples were fixed in $4 \%$ paraformaldehyde for $24 \mathrm{~h}$ and then embedded in paraffin wax. Sections $4 \mu \mathrm{m}$ thick were cut and stained with hematoxylin and eosin. In each cross section of tissue, at least 6 complete villous-crypt structures were examined under a microscope, and villous height and crypt depth were measured using an Image Pro-Plus 6.0 Software Analysis System (Media Cybernetics, Singapore).

\subsection{Antioxidative Physiological Analyses}

Activity of total superoxide dismutase (T-SOD), glutathione peroxidase (GSH-Px), catalase (CAT), total antioxidant capacity (T-AOC) and malondialdehyde (MDA) in serum, heart, liver, kidney and jejunum were determined using assay kits according to the manufacturer's instructions (Nanjing Jiancheng Bioengineering Institute, Nanjing, China).

\subsection{Statistical Analysis}

All experimental data were analyzed using the GLM procedure in SAS (SAS Inst. Inc., Cary, NC, Canada) and repeated measurements were considered when analyzing the effects of growth performance. Mean values are reported as LS mean \pm S.E. Differences in diarrhea incidence among treatments were tested by a chi-square test. Pen was the experimental unit for performance traits, and individual pig was the experimental unit for all other traits studied. Additionally, all data except diarrhea incidence of the experiment followed a normal distribution. Treatment effects were considered significant at $p<0.05$.

\section{Results}

\subsection{Performance and Diarrhea Incidence}

The effects of weaning age on ADG, ADFI and F:G are presented in Table 2. Pigs weaned at $28 \mathrm{~d}$ had an increased ADG from d 8 to $14(p<0.01)$ than pigs weaned at $21 \mathrm{~d}$. Pigs weaned at $28 \mathrm{~d}$ had a higher ADFI from d 0 to $7(p<0.01), \mathrm{d} 8$ to $14(p<0.01), \mathrm{d} 15$ to $28(p<0.05)$ and during the entire experimental period $(p<0.01)$ than pigs weaned at $21 \mathrm{~d}$. Pigs weaned at $21 \mathrm{~d}$ had an improved F:G from d 15 to $28(p<0.05)$ compared with pigs weaned at $28 \mathrm{~d}$. No difference was observed in final body weight (56 d) among the two groups $(p>0.05)$.

Diarrhea incidence is exhibited in Table 3. Pigs weaned at $28 \mathrm{~d}$ had a decreased incidence of diarrhea compared with pigs weaned at $21 \mathrm{~d}$ from $\mathrm{d} 8$ to $14(p<0.01)$ and the entire experimental period $(p<0.01)$. 


\subsection{Gastrointestinal $p H$ of Piglets}

Results on $\mathrm{pH}$ in the gastrointestinal tract are presented in Table 4 . On d 28, the $\mathrm{pH}$ of stomach contents from pigs weaned at $21 \mathrm{~d}$ was significantly higher compared with pigs weaned at $28 \mathrm{~d}(p<0.01)$. During the entire experimental period, there was no significant difference in $\mathrm{pH}$ of the content of the jejunum, ileum, cecum and colon.

\subsection{Villous Morphology in the Small Intestine}

Effects of weaning age on villous morphology in the small intestine of weaned pigs are presented in Tables 5-7. In the duodenum, pigs weaned at $28 \mathrm{~d}$ showed greater villus height:crypt depth $(p<0.05)$ on $\mathrm{d} 14$ compared with pigs weaned at $21 \mathrm{~d}$. In the jejunum, pigs weaned at $28 \mathrm{~d}$ showed greater villus height and villus height:crypt depth $(p<0.05)$ on $\mathrm{d} 14$ compared with pigs weaned at $21 \mathrm{~d}$. In the ileum, pigs weaned at $28 \mathrm{~d}$ expressed increased villus height $(p<0.05)$ on $\mathrm{d} 14$ compared with pigs weaned at $21 \mathrm{~d}$.

\subsection{Redox Status}

Weaning age influenced antioxidative enzymes in many tissues. In the heart, pigs weaned at $28 \mathrm{~d}$ had increased activities of T-SOD $(p<0.05)$ and decreased concentration of MDA $(p<0.05)$ on d 14 and increased activities of CAT $(p<0.05)$ and decreased concentration of MDA $(p<0.01)$ on d 28 compared with pigs weaned at $21 \mathrm{~d}$ (Table 8). In the liver, pigs weaned at $28 \mathrm{~d}$ had increased activities of T-SOD $(p<0.05)$ and decreased concentration of MDA $(p<0.01)$ on $\mathrm{d} 14$ and 28 compared with pigs weaned at $21 \mathrm{~d}$ (Table 9). In the kidney, pigs weaned at $28 \mathrm{~d}$ had increased activities of T-SOD $(p<0.05)$, GSH-Px $(p<0.05)$ and CAT $(p<0.05)$ and decreased concentration of MDA $(p<0.05)$ on $\mathrm{d} 14$ compared with pigs weaned at $21 \mathrm{~d}$ (Table 10). In the jejunum, pigs weaned at $28 \mathrm{~d}$ had increased activities of T-SOD $(p<0.05)$ and decreased concentration of MDA $(p<0.05)$ on d 14 and increased activities of GSH-Px $(p<0.01)$ and CAT $(p<0.01)$ and decreased concentration of MDA $(p<0.01)$ on d 28 compared with pigs weaned at $21 \mathrm{~d}$ (Table 11). In serum, pigs weaned at $28 \mathrm{~d}$ had increased activities of T-SOD $(p<0.05)$ and T-AOC $(p<0.01)$ and decreased concentration of MDA $(p<0.05)$ on $d 14$ compared with pigs weaned at $21 \mathrm{~d}$ (Table 12).

Table 2. Effect of weaning age on growth performance of weaned pigs ${ }^{1}$.

\begin{tabular}{|c|c|c|c|c|}
\hline \multirow{2}{*}{ Item $^{2}$} & \multicolumn{2}{|c|}{ Weaning Age } & \multirow{2}{*}{ SEM } & \multirow{2}{*}{$p$ Value } \\
\hline & 21 Days of Age & 28 Days of Age & & \\
\hline Initial BW (14 days of age), kg & 5.14 & 5.12 & 0.06 & 0.791 \\
\hline Weaning BW, kg & 6.87 & 8.49 & 0.59 & 0.044 \\
\hline Final BW (56 days of age), kg & 15.78 & 16.90 & 0.53 & 0.141 \\
\hline \multicolumn{5}{|l|}{0 to 7 days after weaning } \\
\hline $\mathrm{ADG}, \mathrm{g} / \mathrm{d}$ & -4 & 36 & 17.86 & 0.113 \\
\hline ADFI, g/d & 93 & 189 & 23.06 & $<0.01$ \\
\hline$F: G$ & / & / & / & / \\
\hline \multicolumn{5}{|l|}{8 to 14 days after weaning } \\
\hline $\mathrm{ADG}, \mathrm{g} / \mathrm{d}$ & 130 & 239 & 32.48 & $<0.01$ \\
\hline ADFI, g/d & 260 & 429 & 38.36 & $<0.01$ \\
\hline$F: G$ & 2.28 & 1.90 & 0.30 & 0.400 \\
\hline \multicolumn{5}{|l|}{15 to 28 days after weaning } \\
\hline $\mathrm{ADG}, \mathrm{g} / \mathrm{d}$ & 357 & 379 & 25.29 & 0.559 \\
\hline ADFI, g/d & 595 & 721 & 43.05 & 0.030 \\
\hline$F: G$ & 1.67 & 1.92 & 0.08 & 0.017 \\
\hline \multicolumn{5}{|l|}{0 to 28 days after weaning } \\
\hline $\mathrm{ADG}, \mathrm{g} / \mathrm{d}$ & 230 & 284 & 21.23 & 0.071 \\
\hline ADFI, $g / d$ & 424 & 561 & 36.66 & $<0.01$ \\
\hline$F: G$ & 1.87 & 2.00 & 0.09 & 0.293 \\
\hline
\end{tabular}

${ }^{1}$ Values are LS means of 6 pens and pooled SEM. ${ }^{2}$ ADG: average daily gain; ADFI: average daily intake; F:G: feed conversion (feed:gain). 
Table 3. Effect of weaning age on diarrhea incidence of weaned pigs ${ }^{1}$.

\begin{tabular}{ccccc}
\hline \multirow{2}{*}{ Item } & \multicolumn{2}{c}{ Weaning Age } & \multirow{2}{*}{ SEM } & \multirow{2}{*}{ Value } \\
& 21 Days of Age & 28 Days of Age & & \\
\hline Diarrhea incidence, ${ }^{2} \%$ & & & & \\
0 to 7 days after weaning & 20.86 & 18.66 & 0.75 & 0.318 \\
8 to 14 days after weaning & 22.56 & 18.28 & 0.88 & $<0.01$ \\
15 to 28 days after weaning & 14.32 & 11.87 & 0.72 & 0.189 \\
0 to 28 days after weaning & 17.59 & 14.77 & 0.70 & $<0.01$ \\
\hline
\end{tabular}

${ }^{1}$ Values are LS means of 6 pens and pooled SEM. ${ }^{2}$ Number of pigs with diarrhea in each pen $\times$ diarrhea days/(total number of pigs $\times 28 \mathrm{~d}$ ) $\times 100$.

Table 4. Effect of weaning age on gastrointestinal $\mathrm{pH}$ of weaned pigs ${ }^{1}$.

\begin{tabular}{|c|c|c|c|c|}
\hline \multirow{2}{*}{ Item } & \multicolumn{2}{|c|}{ Weaning Age } & \multirow{2}{*}{ SEM } & \multirow{2}{*}{$p$ Value } \\
\hline & 21 Days of Age & 28 Days of Age & & \\
\hline \multicolumn{5}{|c|}{7 days after weaning } \\
\hline Stomach & 3.47 & 3.32 & 0.38 & 0.802 \\
\hline Jejunum & 6.01 & 5.80 & 0.15 & 0.354 \\
\hline Ileum & 6.59 & 6.60 & 0.20 & 0.991 \\
\hline Cecum & 6.03 & 5.76 & 0.23 & 0.428 \\
\hline Colon & 6.09 & 6.03 & 0.17 & 0.838 \\
\hline \multicolumn{5}{|c|}{14 days after weaning } \\
\hline Stomach & 3.51 & 3.15 & 0.40 & 0.557 \\
\hline Jejunum & 5.76 & 5.61 & 0.08 & 0.209 \\
\hline Ileum & 6.80 & 6.80 & 0.17 & 0.985 \\
\hline Cecum & 5.95 & 5.73 & 0.14 & 0.278 \\
\hline Colon & 6.18 & 5.76 & 0.12 & 0.166 \\
\hline \multicolumn{5}{|c|}{28 days after weaning } \\
\hline Stomach & 4.19 & 2.62 & 0.45 & $<0.01$ \\
\hline Jejunum & 5.74 & 5.73 & 0.10 & 0.957 \\
\hline Ileum & 7.17 & 7.20 & 0.10 & 0.748 \\
\hline Cecum & 5.47 & 5.60 & 0.08 & 0.267 \\
\hline Colon & 5.68 & 5.84 & 0.08 & 0.132 \\
\hline
\end{tabular}

${ }^{1}$ Values are LS means of 6 pens and pooled SEM.

Table 5. Effect of weaning age on morphology of duodenum in weaned pigs ${ }^{1}$.

\begin{tabular}{|c|c|c|c|c|}
\hline \multirow{2}{*}{ Item } & \multicolumn{2}{|c|}{ Weaning Age } & \multirow{2}{*}{ SEM } & \multirow{2}{*}{$p$ Value } \\
\hline & 21 Days of Age & 28 Days of Age & & \\
\hline \multicolumn{5}{|l|}{7 days after weaning } \\
\hline Villus height, $\mu \mathrm{m}$ & 197 & 234 & 26 & 0.343 \\
\hline Crypt depth, $\mu \mathrm{m}$ & 124 & 107 & 10 & 0.220 \\
\hline Villus height:crypt depth & 1.69 & 2.22 & 0.29 & 0.221 \\
\hline \multicolumn{5}{|l|}{14 days after weaning } \\
\hline Villus height, $\mu \mathrm{m}$ & 231 & 293 & 31 & 0.173 \\
\hline Crypt depth, $\mu \mathrm{m}$ & 162 & 126 & 13 & 0.052 \\
\hline Villus height:crypt depth & 1.50 & 2.34 & 0.27 & 0.018 \\
\hline \multicolumn{5}{|l|}{28 days after weaning } \\
\hline Villus height, $\mu \mathrm{m}$ & 377 & 359 & 29 & 0.692 \\
\hline Crypt depth, $\mu \mathrm{m}$ & 160 & 142 & 12 & 0.338 \\
\hline Villus height:crypt depth & 2.36 & 2.55 & 0.14 & 0.354 \\
\hline
\end{tabular}

${ }^{1}$ Values are LS means of 6 pens and pooled SEM. 
Table 6. Effect of weaning age on morphology of jejunum in weaned pigs ${ }^{1}$.

\begin{tabular}{|c|c|c|c|c|}
\hline \multirow{2}{*}{ Item } & \multicolumn{2}{|c|}{ Weaning Age } & \multirow{2}{*}{ SEM } & \multirow{2}{*}{$p$ Value } \\
\hline & 21 Days of Age & 28 Days of Age & & \\
\hline \multicolumn{5}{|l|}{7 days after weaning } \\
\hline Villus height, $\mu \mathrm{m}$ & 323 & 352 & 38 & 0.609 \\
\hline Crypt depth, $\mu \mathrm{m}$ & 124 & 115 & 9 & 0.570 \\
\hline Villus height:crypt depth & 2.71 & 3.11 & 0.39 & 0.500 \\
\hline \multicolumn{5}{|l|}{14 days after weaning } \\
\hline Villus height, $\mu \mathrm{m}$ & 241 & 343 & 36 & 0.045 \\
\hline Crypt depth, $\mu \mathrm{m}$ & 126 & 114 & 6 & 0.252 \\
\hline Villus height:crypt depth & 1.96 & 3.01 & 0.34 & 0.018 \\
\hline \multicolumn{5}{|l|}{28 days after weaning } \\
\hline Villus height, $\mu \mathrm{m}$ & 380 & 384 & 29 & 0.939 \\
\hline Crypt depth, $\mu \mathrm{m}$ & 142 & 113 & 14 & 0.148 \\
\hline Villus height:crypt depth & 2.86 & 3.48 & 0.40 & 0.295 \\
\hline
\end{tabular}

${ }^{1}$ Values are LS means of 6 pens and pooled SEM.

Table 7. Effect of weaning age on morphology of ileum in weaned pigs ${ }^{1}$.

\begin{tabular}{|c|c|c|c|c|}
\hline \multirow{2}{*}{ Item } & \multicolumn{2}{|c|}{ Weaning Age } & \multirow[b]{2}{*}{ SEM } & \multirow{2}{*}{$p$ Value } \\
\hline & 21 Days of Age & 28 Days of Age & & \\
\hline \multicolumn{5}{|l|}{7 days after weaning } \\
\hline Villus height, $\mu \mathrm{m}$ & 288 & 291 & 18 & 0.935 \\
\hline Crypt depth, $\mu \mathrm{m}$ & 161 & 132 & 13 & 0.108 \\
\hline Villus height:crypt depth & 1.83 & 2.27 & 0.21 & 0.148 \\
\hline \multicolumn{5}{|l|}{14 days after weaning } \\
\hline Villus height, $\mu \mathrm{m}$ & 290 & 406 & 38 & 0.024 \\
\hline Crypt depth, $\mu \mathrm{m}$ & 120 & 129 & 15 & 0.686 \\
\hline Villus height:crypt depth & 2.70 & 3.25 & 0.46 & 0.422 \\
\hline \multicolumn{5}{|l|}{28 days after weaning } \\
\hline Villus height, $\mu \mathrm{m}$ & 381 & 422 & 42 & 0.395 \\
\hline Crypt depth, $\mu \mathrm{m}$ & 152 & 156 & 12 & 0.840 \\
\hline Villus height:crypt depth & 2.50 & 2.85 & 0.20 & 0.344 \\
\hline
\end{tabular}

${ }^{1}$ Values are LS means of 6 pens and pooled SEM.

Table 8. Effect of weaning age on heart antioxidant indexes of weaned pigs ${ }^{1}$.

\begin{tabular}{|c|c|c|c|c|}
\hline \multirow{2}{*}{ Item $^{2}$} & \multicolumn{2}{|c|}{ Weaning Age } & \multirow{2}{*}{ SEM } & \multirow{2}{*}{$p$ Value } \\
\hline & 21 Days of Age & 28 Days of Age & & \\
\hline \multicolumn{5}{|l|}{14 days after weaning } \\
\hline T-SOD, U/mg & 107.98 & 126.74 & 5.39 & $<0.01$ \\
\hline GSH-Px, U/mg & 639.20 & 698.14 & 46.58 & 0.433 \\
\hline $\mathrm{CAT}, \mathrm{U} / \mathrm{mg}$ & 0.96 & 1.03 & 0.07 & 0.547 \\
\hline T-AOC, U/mg & 2.62 & 2.27 & 0.23 & 0.324 \\
\hline $\mathrm{MDA}, \mathrm{nmol} / \mathrm{mg}$ & 2.96 & 1.90 & 0.35 & 0.033 \\
\hline \multicolumn{5}{|l|}{28 days after weaning } \\
\hline T-SOD, U/mg & 112.96 & 116.47 & 3.46 & 0.523 \\
\hline GSH-Px, U/mg & 708.62 & 712.69 & 36.45 & 0.945 \\
\hline CAT, U/mg & 0.65 & 1.20 & 0.18 & 0.025 \\
\hline T-AOC, U/mg & 2.90 & 3.40 & 0.533 & 0.557 \\
\hline $\mathrm{MDA}, \mathrm{nmol} / \mathrm{mg}$ & 2.34 & 1.39 & 0.25 & $<0.01$ \\
\hline
\end{tabular}

${ }^{1}$ Values are LS means of 6 pens and pooled SEM. ${ }^{2}$ T-SOD: total superoxide dismutase; GSH-Px: glutathione peroxidase; CAT: catalase; T-AOC: total antioxidant capacity; MDA: malondialdehyde. 
Table 9. Effect of weaning age on liver antioxidant indexes of weaned pigs ${ }^{1}$.

\begin{tabular}{|c|c|c|c|c|}
\hline \multirow{2}{*}{ Item $^{2}$} & \multicolumn{2}{|c|}{ Weaning Age } & \multirow{2}{*}{ SEM } & \multirow{2}{*}{$p$ Value } \\
\hline & 21 Days of Age & 28 Days of Age & & \\
\hline \multicolumn{5}{|l|}{14 days after weaning } \\
\hline T-SOD, U/mg & 60.09 & 67.67 & 2.43 & 0.039 \\
\hline GSH-Px, U/mg & 600.34 & 632.98 & 38.70 & 0.623 \\
\hline CAT, $\mathrm{U} / \mathrm{mg}$ & 2.46 & 2.69 & 0.15 & 0.348 \\
\hline $\mathrm{T}-\mathrm{AOC}, \mathrm{U} / \mathrm{mg}$ & 3.67 & 4.43 & 0.38 & 0.221 \\
\hline $\mathrm{MDA}, \mathrm{nmol} / \mathrm{mg}$ & 7.15 & 6.11 & 0.27 & $<0.01$ \\
\hline \multicolumn{5}{|l|}{28 days after weaning } \\
\hline $\mathrm{T}-\mathrm{SOD}, \mathrm{U} / \mathrm{mg}$ & 58.57 & 66.51 & 2.76 & 0.045 \\
\hline GSH-Px, U/mg & 539.82 & 603.17 & 41.39 & 0.301 \\
\hline $\mathrm{CAT}, \mathrm{U} / \mathrm{mg}$ & 2.29 & 2.06 & 0.20 & 0.449 \\
\hline $\mathrm{T}-\mathrm{AOC}, \mathrm{U} / \mathrm{mg}$ & 4.11 & 3.70 & 0.29 & 0.340 \\
\hline $\mathrm{MDA}, \mathrm{nmol} / \mathrm{mg}$ & 7.08 & 5.81 & 0.36 & $<0.01$ \\
\hline
\end{tabular}

${ }^{1}$ Values are LS means of 6 pens and pooled SEM. ${ }^{2}$ T-SOD: total superoxide dismutase; GSH-Px: glutathione peroxidase; CAT: catalase; T-AOC: total antioxidant capacity; MDA: malondialdehyde.

Table 10. Effect of weaning age on kidney antioxidant indexes of weaned pigs ${ }^{1}$.

\begin{tabular}{|c|c|c|c|c|}
\hline \multirow{2}{*}{ Item $^{2}$} & \multicolumn{2}{|c|}{ Weaning Age } & \multirow{2}{*}{ SEM } & \multirow{2}{*}{$p$ Value } \\
\hline & 21 Days of Age & 28 Days of Age & & \\
\hline \multicolumn{5}{|l|}{14 days after weaning } \\
\hline T-SOD, U/mg & 77.96 & 96.70 & 6.45 & 0.032 \\
\hline GSH-Px, U/mg & 655.46 & 794.84 & 47.12 & 0.037 \\
\hline $\mathrm{CAT}, \mathrm{U} / \mathrm{mg}$ & 3.29 & 4.19 & 0.30 & 0.026 \\
\hline T-AOC, U/mg & 3.84 & 5.07 & 0.50 & 0.085 \\
\hline $\mathrm{MDA}, \mathrm{nmol} / \mathrm{mg}$ & 5.29 & 3.21 & 0.72 & 0.033 \\
\hline \multicolumn{5}{|l|}{28 days after weaning } \\
\hline T-SOD, U/mg & 79.00 & 82.84 & 5.49 & 0.643 \\
\hline GSH-Px, U/mg & 671.62 & 703.04 & 35.13 & 0.553 \\
\hline $\mathrm{CAT}, \mathrm{U} / \mathrm{mg}$ & 3.61 & 3.40 & 0.26 & 0.595 \\
\hline T-AOC, U/mg & 4.83 & 4.27 & 0.24 & 0.186 \\
\hline $\mathrm{MDA}, \mathrm{nmol} / \mathrm{mg}$ & 4.89 & 5.05 & 0.46 & 0.818 \\
\hline
\end{tabular}

${ }^{1}$ Values are LS means of 6 pens and pooled SEM. ${ }^{2}$ T-SOD: total superoxide dismutase; GSH-Px: glutathione peroxidase; CAT: catalase; T-AOC: total antioxidant capacity; MDA: malondialdehyde.

Table 11. Effect of weaning age on jejunum antioxidant indexes of weaned pigs ${ }^{1}$.

\begin{tabular}{ccccc}
\hline \multirow{2}{*}{ Item $^{2}$} & \multicolumn{2}{c}{ Weaning Age } & \multirow{2}{*}{ SEM } & \multirow{2}{*}{ 位alue } \\
& 21 Days of Age & 28 Days of Age & & \\
\hline 14 days after weaning & & & & \\
T-SOD, U/mg & 60.19 & 80.08 & 7.23 & 0.045 \\
GSH-Px, U/mg & 544.63 & 484.12 & 41.52 & 0.326 \\
CAT, U/mg & 2.62 & 2.72 & 0.18 & 0.698 \\
T-AOC, U/mg & 3.78 & 3.60 & 0.39 & 0.763 \\
MDA, nmol/mg & 6.19 & 3.65 & 0.68 & $<0.01$ \\
28 days after weaning & & & & \\
T-SOD, U/mg & 60.53 & 66.08 & 6.18 & 0.551 \\
GSH-Px, U/mg & 369.81 & 667.38 & 63.09 & $<0.01$ \\
CAT, U/mg & 2.50 & 3.25 & 0.22 & $<0.01$ \\
T-AOC, U/mg & 3.14 & 3.42 & 0.35 & 0.613 \\
MDA, nmol/mg & 6.50 & 4.14 & 0.71 & $<0.01$ \\
\hline
\end{tabular}

${ }^{1}$ Values are LS means of 6 pens and pooled SEM. ${ }^{2}$ T-SOD: total superoxide dismutase; GSH-Px: glutathione peroxidase; CAT: catalase; T-AOC: total antioxidant capacity; MDA: malondialdehyde. 
Table 12. Effect of weaning age on serum antioxidant indexes of weaned pigs ${ }^{1}$.

\begin{tabular}{|c|c|c|c|c|}
\hline \multirow{2}{*}{ Item $^{2}$} & \multicolumn{2}{|c|}{ Weaning Age } & \multirow{2}{*}{ SEM } & \multirow{2}{*}{$p$ Value } \\
\hline & 21 Days of Age & 28 Days of Age & & \\
\hline \multicolumn{5}{|l|}{14 days after weaning } \\
\hline T-SOD, U/mL & 147.94 & 153.43 & 1.77 & 0.019 \\
\hline GSH-Px, U/mL & 826.14 & 829.41 & 35.80 & 0.952 \\
\hline $\mathrm{CAT}, \mathrm{U} / \mathrm{mL}$ & 5.96 & 6.06 & 0.55 & 0.906 \\
\hline $\mathrm{T}-\mathrm{AOC}, \mathrm{U} / \mathrm{mL}$ & 6.31 & 8.74 & 0.68 & $<0.01$ \\
\hline $\mathrm{MDA}, \mathrm{nmol} / \mathrm{mL}$ & 4.32 & 3.79 & 0.20 & 0.050 \\
\hline \multicolumn{5}{|l|}{28 days after weaning } \\
\hline $\mathrm{T}-\mathrm{SOD}, \mathrm{U} / \mathrm{mL}$ & 153.37 & 151.33 & 2.36 & 0.566 \\
\hline GSH-Px, U/mL & 787.58 & 881.70 & 42.65 & 0.123 \\
\hline $\mathrm{CAT}, \mathrm{U} / \mathrm{mL}$ & 5.91 & 6.76 & 0.49 & 0.240 \\
\hline T-AOC, U/mL & 7.34 & 6.37 & 0.44 & 0.174 \\
\hline $\mathrm{MDA}, \mathrm{nmol} / \mathrm{mL}$ & 4.01 & 3.84 & 0.30 & 0.706 \\
\hline
\end{tabular}

${ }^{1}$ Values are LS means of 6 pens and pooled SEM. ${ }^{2}$ T-SOD: total superoxide dismutase; GSH-Px: glutathione peroxidase; CAT: catalase; T-AOC: total antioxidant capacity; MDA: malondialdehyde.

\section{Discussion}

Weaning is an inevitable process for pigs. Due to the various changes in diet and the environment during weaning, pigs experience intense stress. Pigs subjected to these stresses typically reduce daily feed intake and weight gain and experience increased occurrence of diarrhea. Weaning stress is longer and more intense when piglets are weaned at an earlier age compared with a later age [24]. Daily feed intake of pigs weaned at $28 \mathrm{~d}$ was increased during the entire experimental period compared with pigs weaned at $21 \mathrm{~d}$. From d 8 to 14 , the ADG of pigs weaned at $28 \mathrm{~d}$ was greater compared with pigs weaned at $21 \mathrm{~d}$. These findings are consistent with other studies showing that improvements in ADG and ADFI after weaning are associated with increased weaning age [9,25]. Importantly, from d 0 to 7 , pigs weaned at $21 \mathrm{~d}$ lost weight. This result suggests that younger piglets have lower ADFI and insufficient digestive capacity than pigs weaned at older ages. Stress on pigs weaned at $21 \mathrm{~d}$ was more severe when fed a diet without antibiotic growth promoters [26]. During the entire experimental period, there were no significant differences in F:G between the two weaning ages. This may reflect limitations in early postweaning digestibility that is independent of weaning age [3]. Moreover, there was no statistical difference between final body weights of the two groups.

Weaning is also an important period for intestinal development of pigs. In our research, pigs weaned at $28 \mathrm{~d}$ showed improved morphology of the duodenum, jejunum and ileum on $\mathrm{d} 14$ compared with pigs weaned at $21 \mathrm{~d}$. Researchers demonstrated that intestinal villus height is positively related to growth performance of pigs postweaning [27]. During weaning, reduced feed intake of pigs resulted in a lack of dietary energy and protein. The regeneration rate of intestinal epithelial cells cannot keep pace with the rate of apoptosis. As a result, villi height became shorter, and crypts became deeper. Consequently, the ratio of villus height to crypt depth, which is used to assess nutrient absorption and digestion, declined, suggesting compromised nutrient uptake [28-30].

In this study, the diarrhea incidence of pigs weaned at $28 \mathrm{~d}$ decreased from $\mathrm{d} 8$ to 14 and the entire experimental period compared with pigs weaned at $21 \mathrm{~d}$. The incidence of diarrhea corresponded with altered villous morphology in the small intestine. Levels of digestive enzymes in the stomach of weaned pigs were low because the gastric fundus gland could not secrete enough hydrochloric acid to support sufficient pepsin activity [31]. As a result, digestion and utilization of protein, especially of plant proteins, were inadequate. We found that the $\mathrm{pH}$ of the stomach decreases over time in pigs weaned at $28 \mathrm{~d}$ while it increases in pigs weaned at $21 \mathrm{~d}$. Insufficient gastric acid secretion also leads to accelerated emptying of the stomach which introduces the inadequately digested feed into the lower portion of the digestive tract [32]. The ability of the stomach and small intestine to absorb nutrients decreases, resulting in excess nutrients entering the hindgut. Excess nutrition in 
the hindgut leads to excessive reproduction of harmful microorganisms, destroying the balance of intestinal microflora and causing diarrhea in piglets.

Weaning also leads to oxidative stress in pigs [14]. During weaning stress, the organs of pigs produce large amounts of free radicals. Free radicals oxidize DNA, proteins and lipids to hydrogen peroxide, which can cause organ and cell damage if produced in excess [33]. It is important to repair and maintain the antioxidant capacity of pigs to combat oxidative stress. Therefore, we measured the antioxidant capacity of several major organs, including the heart, liver, kidneys and intestines, as well as the serum. In this study, the antioxidant capacity of pigs weaned at $28 \mathrm{~d}$ was slightly better than pigs weaned at $21 \mathrm{~d}$ in the heart, liver, kidney, jejunum and serum. The antioxidant function of pigs is related to growth performance, intestinal absorption and immune function [34,35]. The antioxidant system of pigs includes antioxidant enzymes such as SOD, GSH-Px and CAT [36]. Superoxide dismutase catalyzes the efficient dismutation of $\mathrm{O}^{2-}$ to $\mathrm{H}_{2} \mathrm{O}_{2}$ which is cleaned by GSH-Px and CAT [37]. T-AOC is a biomarker for oxidative stress and antioxidant defense and is the criterion for assessing a healthy body state [38]. The antioxidant enzyme activities can effectively protect the structure and functional integrity of cell membranes, and are the main components of important antioxidant systems in the body [39]. Pigs weaned at $28 \mathrm{~d}$ had better antioxidant capacity than pigs weaned at $21 \mathrm{~d}$. MDA is a naturally occurring product of prostaglandin biosynthesis and lipid peroxidation and is an indicator of lipid peroxidation [40]. In particular, pigs weaned at $21 \mathrm{~d}$ had higher concentrations of MDA in the heart, liver, kidney, jejunum and serum, which indicated that lipid peroxidation was more serious than in pigs weaned at $28 \mathrm{~d}$. The result of redox status indicated that pigs weaned at $28 \mathrm{~d}$ suffered less weaning stress than pigs weaned at $21 \mathrm{~d}$.

\section{Conclusions}

In conclusion, our results showed that intestinal morphology, $\mathrm{pH}$ of the stomach and antioxidant status of pigs weaned at $28 \mathrm{~d}$ were more robust than in pigs weaned at $21 \mathrm{~d}$ without antibiotic use. Weaning at 28 days was better for the growth of pigs under the current experimental condition. These results indicated that compared with pigs weaned at $28 \mathrm{~d}$, one of the vitally important strategies to improve growth performance and decrease diarrhea incidence without antibiotic use for pigs weaned at $21 \mathrm{~d}$ is enhancing antioxidant ability. The possible effects (positive or negative) on the sows could be investigated in further studies.

Author Contributions: D.M.: Conceptualization, Investigation, Methodology, Data curation, Formal analysis, Writing —original draft; W.W.: Methodology, Data curation; C.H.: Methodology, Data curation; Z.W.: Methodology, Data curation; C.S.: Methodology, Data curation; J.D.: Methodology, Data curation; H.L.: Methodology, Conceptualization, Writing-review, Supervision; F.W.: Conceptualization, Writing - review, Supervision, Funding acquisition. All authors have read and agreed to the published version of the manuscript.

Funding: This research was funded by the National Natural Science Foundation of China, grant number 31672459 and 32072772.

Institutional Review Board Statement: China Agricultural University Laboratory Animal Welfare and Animal Experimental Ethical Inspection, No. AW30301201-1-1.

Informed Consent Statement: Informed consent was obtained from all subjects involved in the study.

Data Availability Statement: Some or all data, models or code generated or used during the study are available in a repository or online in accordance with funder data retention policies (Provide full citations that include URLs or DOIs.)

Acknowledgments: The writers express their thanks to Lee. J. Johnston (University of Minnesota) and B. Dong (China Agricultural University) for modification of the manuscript. We also thank all employees of the Fengning Experimental Base (China Agricultural University, Beijing, China) for helpful technical assistance.

Conflicts of Interest: The authors declare no conflict of interest. 


\section{References}

1. Pluske, J.; Hampson, D.; Williams, I.H. Factors influencing the structure and function of the small intestine in the weaned pig: A review. Livest. Prod. Sci. 1997, 51, 215-236. [CrossRef]

2. Jarvis, S.; Moinard, C.; Robson, S.K.; Sumner, B.E.; Douglas, A.J.; Seckl, J.R.; Russell, J.A.; Lawrence, A. Effects of weaning age on the behavioural and neuroendocrine development of piglets. Appl. Anim. Behav. Sci. 2008, 110, 166-181. [CrossRef]

3. Hou, C.; Zeng, X.; Yang, F.; Liu, H.; Qiao, S. Study and use of the probiotic Lactobacillus reuteri in pigs: A review. J. Anim. Sci. Biotechnol. 2015, 6, 1-8. [CrossRef] [PubMed]

4. Qu, H.; Cheng, Y.; Chen, Y.; Li, J.; Zhao, Y.; Zhou, Y. Effects of Dietary Zeolite Supplementation as an Antibiotic Alternative on Growth Performance, Intestinal Integrity, and Cecal Antibiotic Resistance Genes Abundances of Broilers. Animals 2019 , 9, 909. [CrossRef] [PubMed]

5. European Commission. Council Directive 2008/120/EC of 18 December 2008 laying down minimum standards for the protec-tion of pigs (codified version). Off. J. Eur. Union 2009, 5-13, L47.

6. Knox, R.V.; Zas, S.L.R.; Sloter, N.L.; McNamara, K.A.; Gall, T.J.; Levis, D.G.; Safranski, T.J.; Singleton, W.L. An analysis of survey data by size of the breeding herd for the reproductive management practices of North American sow farms. J. Anim. Sci. 2013, 91, 433-445. [CrossRef]

7. Leliveld, L.; Riemensperger, A.; Gardiner, G.; O'Doherty, J.; Lynch, P.; Lawlor, P. Effect of weaning age and postweaning feeding programme on the growth performance of pigs to 10 weeks of age. Livest. Sci. 2013, 157, 225-233. [CrossRef]

8. Buchet, A.; Belloc, C.; Leblanc-Maridor, M.; Merlot, E. Effects of age and weaning conditions on blood indicators of oxidative status in pigs. PLoS ONE 2017, 12, e0178487. [CrossRef]

9. Main, R.G.; Dritz, S.S.; Tokach, M.D.; Goodband, R.D.; Nelssen, J.L. Increasing weaning age improves pig performance in a multisite production system1. J. Anim. Sci. 2004, 82, 1499-1507. [CrossRef] [PubMed]

10. Do, C.H. Estimation of Weaning Age Effects on Growth Performance in Berkshire Pigs. Asian-Australas. J. Anim. Sci. 2011, 25, 151-162. [CrossRef]

11. McLamb, B.L.; Gibson, A.J.; Overman, E.L.; Stahl, C.; Moeser, A.J. Early Weaning Stress in Pigs Impairs Innate Mucosal Immune Responses to Enterotoxigenic E. coli Challenge and Exacerbates Intestinal Injury and Clinical Disease. PLoS ONE 2013, 8, e59838. [CrossRef] [PubMed]

12. Faccin, J.E.G.; Laskoski, F.; Hernig, L.F.; Kummer, R.; Lima, G.F.R.; Orlando, U.A.D.; Gonçalves, M.A.D.; Mellagi, A.P.G.; Ulguim, R.R.; Bortolozzo, F.P. Impact of increasing weaning age on pig performance and belly nosing prevalence in a commercial multisite production system. J. Anim. Sci. 2020, 98, 4. [CrossRef] [PubMed]

13. Faccin, J.E.G.; Tokach, M.D.; Allerson, M.W.; Woodworth, J.C.; DeRouchey, J.M.; Dritz, S.S.; Bortolozzo, F.P.; Goodband, R.D. Relationship between weaning age and antibiotic usage on pig growth performance and mortality. J. Anim. Sci. 2020, 98. [CrossRef] [PubMed]

14. Zhu, L.H.; Zhao, K.L.; Chen, X.L.; Xu, J.X. Impact of weaning and an antioxidant blend on intestinal barrier function and antioxidant status in pigs. J. Anim. Sci. 2012, 90, 2581-2589. [CrossRef] [PubMed]

15. Yin, J.; Ren, W.K.; Wu, X.S.; Yang, G.; Wang, J.; Li, T.J.; Ding, J.N.; Cai, L.C.; Su, D.D. Oxidative stress-mediated signaling pathways: A review. J. Food Agric. Environ. 2013, 11, 132-139.

16. Boudry, G.; Péron, V.; Luron, I.; Lallès, J.-P.; Sève, B. Weaning Induces Both Transient and Long-Lasting Modifications of Absorptive, Secretory, and Barrier Properties of Piglet Intestine. J. Nutr. 2004, 134, 2256-2262. [CrossRef]

17. Madara, J.L. Warner-Lambert/Parke-Davis Award lecture. Pathobiology of the intestinal epithelial barrier. Am. J. Pathol. 1990, 137, 1273-1281.

18. Nabuurs, M. Weaning piglets as a model for studying pathophysiology of diarrhea. Veter Q. 1998, 20, 42-45. [CrossRef]

19. Bard, M.R.; Goettler, C.E.; Toschlog, E.A.; Sagraves, S.G.; Schenarts, P.J.; Newell, M.A.; Fugate, M.; Rotondo, M.F. Alcohol Withdrawal Syndrome: Turning Minor Injuries into a Major Problem. J. Trauma: Inj. Infect. Crit. Care 2006, 61, 1441-1446. [CrossRef]

20. NRC. Nutrient Requirements of Swine, 11th ed.; The National Academies Press: Washington, DC, USA, 2012.

21. Marquardt, R. Passive protective effect of egg-yolk antibodies against enterotoxigenic Escherichia coli K88+ infection in neonatal and early-weaned piglets. FEMS Immunol. Med Microbiol. 1999, 23, 283-288. [CrossRef]

22. Ou, D.; Li, D.; Cao, Y.; Li, X.; Yin, J.; Qiao, S.; Wu, G. Dietary supplementation with zinc oxide decreases expression of the stem cell factor in the small intestine of weanling pigs. J. Nutr. Biochem. 2007, 18, 820-826. [CrossRef] [PubMed]

23. AOAC. Official Methods of Analysis, 19th ed.; Association of Official Agricultural Chemists: Arlington, VA, USA, 2012.

24. Colson, V.; Orgeur, P.; Foury, A.; Mormède, P. Consequences of weaning piglets at 21 and 28 days on growth, behaviour and hormonal responses. Appl. Anim. Behav. Sci. 2006, 98, 70-88. [CrossRef]

25. Hohenshell, L.M.; Cunnick, J.E.; Ford, S.P.; Kattesh, H.G.; Zimmerman, D.R.; Wilson, M.E.; Matteri, R.L.; Carroll, J.; Lay, D.C. Few differences found between early- and late-weaned pigs raised in the same environment. J. Anim. Sci. 2000, 78, 38-49. [CrossRef] [PubMed]

26. Dupont, J.; Ewens-Luby, S.; Mathias, M.M. Cholesterol metabolism in relation to aging and dietary fat in rats and humans. Lipids 1985, 20, 825-833. [CrossRef]

27. McGuinness, M.; Cogburn, L. Response of young broiler chickens to chronic injection of recombinant-derived human insulin-like growth factor-I. Domest. Anim. Endocrinol. 1991, 8, 611-620. [CrossRef] 
28. Pluske, J.; Williams, I.H.; Aherne, F.X. Villous height and crypt depth in piglets in response to increases in the intake of cows' milk after weaning. Anim. Sci. 1996, 62, 145-158. [CrossRef]

29. Montagne, L.; Boudry, G.; Favier, C.; Luron, I.; Lallès, J.-P.; Sève, B. Main intestinal markers associated with the changes in gut architecture and function in piglets after weaning. Br. J. Nutr. 2007, 97, 45-57. [CrossRef]

30. Pluske, J.R.; Kerton, D.J.; Cranwell, P.D.; Campbell, R.G.; Mullan, B.P.; King, R.H.; Power, G.N.; Pierzynowski, S.G.; Westrom, B.; Rippe, C.; et al. Age, sex, and weight at weaning influence organ weight and gastrointestinal devel-opment of weanling pigs. Aust. J. Agric. Res. 2003, 54, 515-527. [CrossRef]

31. Suiryanrayna, M.V.A.N.; Ramana, J.V. A review of the effects of dietary organic acids fed to swine. J. Anim. Sci. Biotechnol. 2015, 6, 1-11. [CrossRef]

32. Van Der Aar, P.; Molist, F.; Van Der Klis, J. The central role of intestinal health on the effect of feed additives on feed intake in swine and poultry. Anim. Feed. Sci. Technol. 2017, 233, 64-75. [CrossRef]

33. Halliwell, B.; Gutteridge, J.M.C. Free Radicals in Biology and Medicine. J. Free. Radic. Biol. Med. 1985, 1, 331-334. [CrossRef]

34. Yin, J.; Wu, M.M.; Xiao, H.; Ren, W.K.; Duan, J.L.; Yang, G.; Li, T.J.; Yin, Y.L. Development of an antioxidant system after early weaning in piglets2. J. Anim. Sci. 2014, 92, 612-619. [CrossRef] [PubMed]

35. Han, X.-Y.; Yan, F.-Y.; Nie, X.-Z.; Xia, W.; Chen, S.; Zhang, X.-X.; Qian, L.-C. Effect of replacing antibiotics using multi-enzyme preparations on production performance and antioxidant activity in piglets. J. Integr. Agric. 2017, 16, 640-647. [CrossRef]

36. Kohen, R.; Nyska, A. Invited Review: Oxidation of Biological Systems: Oxidative Stress Phenomena, Antioxidants, Redox Reactions, and Methods for Their Quantification. Toxicol. Pathol. 2002, 30, 620-650. [CrossRef] [PubMed]

37. Poprac, P.; Jomova, K.; Simunkova, M.; Kollar, V.; Rhodes, C.J.; Valko, M. Targeting Free Radicals in Oxidative Stress-Related Human Diseases. Trends Pharmacol. Sci. 2017, 38, 592-607. [CrossRef]

38. Kusano, C.; Ferrari, B. Total Antioxidant Capacity: A biomarker in biomedical and nutritional studies. J. Cell Mol. Biol. 2008, 7, $1-15$.

39. Chen, J.; Li, Y.; Yu, B.; Chen, D.; Mao, X.; Zheng, P.; Luo, J.; He, J. Dietary chlorogenic acid improves growth performance of weaned pigs through maintaining antioxidant capacity and intestinal digestion and absorption function. J. Anim. Sci. 2018, 96, 1108-1118. [CrossRef]

40. Ellah, M.R.A.; Okada, K.; Goryo, M.; Yasuda, J. Levels of malondialdehyde and 4-hydroxyalkenals in bovine liver biopsy. Comp. Haematol. Int. 2012, 22, 823-827. [CrossRef] 